\title{
SPAWNING PERIODICITY OF SEA URCHINS AT SETO -II. DIADEMA SETOSUM-
}

AUTHOR(S):

Kobayashi, Naomasa; Nakamura, Kenji

\section{CITATION:}

Kobayashi, Naomasa ...[et al]. SPAWNING PERIODICITY OF SEA URCHINS AT SETO -II. DIADEMA SETOSUM-. PUBLICATIONS OF THE SETO MARINE BIOLOGICAL LABORATORY 1967, 15(3): 173-184

ISSUE DATE:

1967-10-30

URL:

http://hdl.handle.net/2433/175468

RIGHT: 


\title{
SPAWNING PERIODICITY OF SEA URCHINS AT SETO \\ II. DIADEMA SETOSUM ${ }^{1)}$
}

\author{
NAOMASA KOBAYASHI \\ Biological Laboratory, Doshisha University \\ and \\ KENJI NAKAMURA \\ Zoological Institute, College of Science, University of Kyoto
}

With 2 Text-figures

Diadema setosum (LESKE) is a kind of sea urchins widely distributed over the tropical and subtropical parts of the Indo-Pacific, its locality reaching northerly the southern coasts of Japan. In the foregoing paper of this series the first author (Kobayashi, 1967) insisted that Mespilia glabulus manifested a hemi-lunar periodicity with regard to the spawning during its breeding season extending from July to August, and suggested that such periodicity might be found commonly in some other sea urchins at Seto. According to Fox (1924 a) Diadema setosum at Suez spawns at each full moon during the breeding season and reproduces again a fresh stock of genital products to be spawned at respective ensuing full moon. Mortensen (1938) admitted Fox's observations of this periodicity as a rare exceptional phenomenon at Suez. On the other hand, Randall, Sahroeder and Starak (1964) seemed to be of the opinion that no lunar periodicity of reproduction of Diadema antillarum was found in the West Indian Region. Furthermore, KĚGǨ̌s (1966) reported that no correlation was found between the moon cycle and the maturity of Paracentrotus lividus and Sphaerechinus granularis in the North Adriatic. In Japan, YosHidd (1952) produced by histological examination of the gonad an evidence reconcilable with Fox's view and KUME and DAN (1957) suggest that Diadema setosum spawns at the night of full moon at Misaki. To approach the problem whether the spawning of Diadema setosum is related to the lunar cycle or it is of a hemi-lunar periodicity, changes in the gonad volume and the germ cell maturity were examined through several days around the new and full moon in July and August, 1966.

1) Contributions from the Seto Marine Biological Laboratory, No. 469 .

Publ. Seto Mar. Biol. Lab., XV (3), 173-184, 1967. (Article 10) 


\section{Material and Method}

At Seto, Diadema setosum is abundant in rocky shore surrounding the Seto Marine Biological Laboratory, being densely crowded below the low water mark during the breeding season. The sea urchins were collected from the shallow water at three different places enough apart from one another, shortly before the water is lowest. The specimens used for observations were all mature individuals with the test volume larger than $18.5 \mathrm{cc}$, over $110 \mathrm{cc}$ at the maximum in both sexes. Daily observations were continued for three periods respectively from the $16 \mathrm{th}$ to the $21 \mathrm{st}$ of July, from the 29th of July to the 3rd of August, and from the 16th to the 18th of August; throughout these periods the new moon was on the 19th of July and on the 16th of August, and the full moon on the 2nd of August.

Table 1a. Classification of maturation grades in female.

\begin{tabular}{|c|c|c|c|c|c|}
\hline $\begin{array}{l}\text { grade of } \\
\text { ripening }\end{array}$ & GT ratio & color of gonad & $\begin{array}{c}\text { texture of gonad } \\
\text { tissue }\end{array}$ & gamete in smear & state of gonad \\
\hline I & $<9.9 \%$ & $\begin{array}{l}\text { dark brownish } \\
\text { yellow }\end{array}$ & very hard & | empty & wholly spent \\
\hline II & $10.0-19.9 \%$ & brownish yellow & coarse & almost empty & spent \\
\hline III & $20.0-29.9 \%$ & yellow & soft & $\begin{array}{l}\text { ova in various } \\
\text { stage of ripening }\end{array}$ & in ripening \\
\hline IV & $30.0-39.9 \%$ & light yellow & softer than III & ova mostly ripen & mature \\
\hline $\mathrm{V}$ & $40.0 \%<$ & same, transparent & very soft & full of ripe ovum & fully matured \\
\hline
\end{tabular}

Table 1b. Classification of maturation grades in male.

\begin{tabular}{c|c|l|l|l|l}
\hline $\begin{array}{c}\text { grade of } \\
\text { ripening }\end{array}$ & GT ratio & color of gonad & $\begin{array}{l}\text { texture of gonad } \\
\text { tissue }\end{array}$ & gamete in smear & state of gonad \\
\hline I & $<9.9 \%$ & $\begin{array}{l}\text { dark brownish } \\
\text { yellow }\end{array}$ & very hard & empty & wholly spent \\
II & $\begin{array}{l}10.0-19.9 \% \\
\text { brownish yellow }\end{array}$ & coarse & almost empty & spent \\
III & $20.0-29.9 \%$ & yellow & $\begin{array}{l}\text { soft } \\
\text { softer than III } \\
\text { full of ripe } \\
\text { sperms }\end{array}$ & ripening \\
IV & $30.0 \%<$ & light yellow & sotured \\
\hline
\end{tabular}

As to respective specimens, the gonad volume was measured and fresh smear preparations of squashed gonad were examined under microscope. As shown in Table 1, the maturation grade of the gonad was divided into five classes in female and four in male, according to the ratio of the gonad volume to the test volume or the GT ratio. This classification is roughly correlated with the differences of the gonad in color and texture of the tissue. The gonadal contents in each maturation grade were quite similar to those described in Mespilia (Kobayashi, 1967). In the preliminary tests, the GT ratio after a forced spawning with $\mathrm{KGl}$ was examined. It was interesting to find that the GT ratio was $15 \%$ at the new moon in July and slightly less than $5 \%$ at the ensuing full moon; the maturation of the gonad was respectively in grade II and in I. There was no noticeable difference between the 
sexes in the maturity. These data mentioned above seem to show that the sea urchins did not become wholly spent after a forced spawning at the new moon, while they became wholly spent at the full moon.

\section{Results}

I. The first period

The period covered six days from July 16 to 21 , the new moon being on the 19th. The results of observations made in this period are summarized in Table $2 a$ and the occurrences of the female and male in respective maturation grades in percent are illustrated in Fig. la, b. None of the wholly spent female of grade $\mathbf{I}$ was found during this period; this can not be accidental, because the females just after the forced spawning with $\mathrm{KCl}$ at the new moon in this period were found in grade II but not in the state of wholly spent. The occurrence of mature female in grade IV and $\mathrm{V}$ was remarkably high on the first day and in the three days before the new moon, but as shown by the solid line in Fig. 1a it decreased with days to the minimum on the day after the new moon and then increased again next day. Spent females in grade II were not found on the first day but appeared next day. The occurrence of the spent female exhibited a striking contrast against that of the mature female, which showed a mode on the day of new moon as shown by the broken line in the figure. The succession found in the occurrences of the female in respective grades is seemingly very suggestive of the maturation rate of the female during this period. On the first day, $25 \%$ of females were in grade III, while the remaining in grade IV; and there was no spent individual. On the second day, about $33 \%$ of females were spent, while $67 \%$ of them were fully mature and in grade $\mathrm{V}$; but there was no female in grade III or IV. These facts seem to suggest that some of the females in grade IV on the first day had spawned and the remaining females in earlier stages of grade IV, together with the females in grade III, were advanced to grade V within 24 hours. On the third day or the day before the new moon, the females of grade III, up to $37.5 \%$, appeared again, while the females in grade II and V were $37.5 \%$ and $25 \%$ respectively; but there was no female in grade IV. This amply suggests that nearly one half of fully mature females on the second day became spent on the third day accomplishing the spawning. On the day of new moon the occurrence of the spent female was remarkably increased to $83 \%$, while the female in grade IV was $17 \%$; there was no female in grade III or V. This shows that a half of females in grade III on the day before became mature on the day of new moon, while females in late grade III or more advanced stages had accomplished the spawning and were already in grade II on that day. On the day next the new moon the spent females decreased very slightly and $20 \%$ of females were found in grade III. Disappearance of the mature female and appearance of the female in grade III indicate that mature females on the day of new moon became spent next day, while some of spent females 
Table 2a. Records of examined individuals in the first period of observation.

\begin{tabular}{|c|c|c|c|c|c|c|}
\hline \multirow[b]{2}{*}{ date } & \multicolumn{3}{|c|}{ female } & \multicolumn{3}{|c|}{ male } \\
\hline & $\begin{array}{l}\text { test volume } \\
\text { (cc) }\end{array}$ & GT ratio & $\begin{array}{l}\text { maturity } \\
\text { grade }\end{array}$ & $\begin{array}{l}\text { test volume } \\
\text { (cc) }\end{array}$ & GT ratio & $\begin{array}{c}\text { maturity } \\
\text { grade }\end{array}$ \\
\hline \multirow[t]{7}{*}{$16 / \mathrm{VII}$} & 19.5 & 25.6 & III & 50.0 & 37.0 & IV \\
\hline & 35.0 & 35.7 & IV & 31.5 & 23.8 & III \\
\hline & 74.0 & 31.8 & IV & 37.0 & 18.4 & II \\
\hline & 71.5 & 37.1 & IV & 22.0 & 25.0 & III \\
\hline & & & & 18.5 & 18.9 & II \\
\hline & & & & 27.5 & 32.7 & IV \\
\hline & & & & 22.5 & 24.4 & III \\
\hline \multirow[t]{8}{*}{$17 / \mathrm{VII}$} & 28.5 & 19.3 & II & 41.0 & 23.2 & III \\
\hline & 37.0 & 45.9 & V & 51.0 & 22.5 & III \\
\hline & 57.5 & 48.7 & V & 71.0 & 27.5 & III \\
\hline & & & & 37.5 & 32.0 & IV \\
\hline & & & & 50.0 & 25.0 & III \\
\hline & & & & 26.5 & 32.1 & IV \\
\hline & & & & 50.0 & 35.0 & IV \\
\hline & & & & 25.0 & 30.0 & IV \\
\hline \multirow[t]{8}{*}{$18 / \mathrm{VII}$} & 28.5 & 40.4 & V & 39.5 & 24.1 & III \\
\hline & 71.5 & 20.3 & III & 50.0 & 27.0 & III \\
\hline & 50.0 & 40.0 & V & 68.5 & 23.4 & III \\
\hline & 34.0 & 17.6 & II & 54.0 & 38.9 & IV \\
\hline & 56.0 & 15.2 & II & 43.0 & 26.7 & III \\
\hline & 70.0 & 18.6 & II & & & \\
\hline & 27.0 & 29.6 & III & & & \\
\hline & 35.0 & 21.4 & III & & & \\
\hline \multirow[t]{10}{*}{$19 / \mathrm{VII}$} & 40.5 & 18.5 & II & 91.5 & 19.1 & II \\
\hline & 77.0 & 13.6 & II & 67.5 & 18.5 & II \\
\hline & 45.5 & 18.7 & II & 57.0 & 19.3 & II \\
\hline & 45.0 & 34.4 & IV & 29.5 & 18.6 & II \\
\hline & 34.5 & 13.0 & II & 30.0 & 20.0 & III \\
\hline & 42.5 & 17.6 & II & 44.5 & 27.0 & III \\
\hline & & & & 30.5 & 21.3 & III \\
\hline & & & & 43.5 & 28.7 & III \\
\hline & & & & 30.5 & 19.7 & II \\
\hline & & & & 57.5 & 20.0 & III \\
\hline \multirow[t]{6}{*}{ 20/VII } & 44.5 & 24.5 & III & 69.5 & 24.5 & III \\
\hline & 68.0 & 16.9 & II & 69.5 & 30.9 & IV \\
\hline & 75.0 & 16.7 & II & 78.0 & 36.5 & IV \\
\hline & 35.0 & 17.0 & II & 93.0 & 31.2 & IV \\
\hline & 63.5 & 17.3 & II & 69.5 & 36.0 & IV \\
\hline & & & & 67.5 & 23.0 & III \\
\hline
\end{tabular}


Table 2a. (continued)

\begin{tabular}{c|c|c|c||c|c|c} 
& \multicolumn{3}{|c||}{ female } & \multicolumn{3}{c}{ male } \\
\cline { 3 - 7 } date & $\begin{array}{c}\text { test volume } \\
\text { (cc) }\end{array}$ & GT ratio & $\begin{array}{c}\text { maturity } \\
\text { grade }\end{array}$ & $\begin{array}{c}\text { test volume } \\
\text { (cc) }\end{array}$ & GT ratio & $\begin{array}{c}\text { maturity } \\
\text { grade }\end{array}$ \\
\hline \multirow{2}{*}{ 21/VII } & 48.5 & 22.7 & III & 58.5 & 12.0 & II \\
& 39.5 & 24.3 & III & 27.5 & 30.0 & IV \\
& 38.5 & 19.5 & II & 38.0 & 11.8 & II \\
& 43.0 & 37.2 & IV & 47.5 & 23.2 & III \\
& 30.0 & 38.3 & IV & 51.0 & 29.4 & III \\
& 33.5 & 34.3 & IV & 32.0 & 17.2 & II \\
\hline
\end{tabular}

advanced to grade III. On the last day of the period, namely two days after the new moon, the proportion of respective grades turned suddenly; mature females in grade IV attained to $50 \%$, females in grade III increased to $34 \%$, while the spent female decreased to $16 \%$. It is surmised that the mature females on that day were derived from the females in grade III and some of the spent individuals in late grade II on the day before. By checking these data, the time duration needed for the maturation of spent females may be roughly estimated. About a half of mature females on the first day became spent next day and then at least one half of those spent females were found matured on the day of new moon or the 4th day of the period, but the other half must have been fully mature on the 3rd day and accomplished the spawning already on the day of new moon. Thus it is supposed that two or three days were needed for the maturation of a batch of germ cells remained in the ovary after the spawning.

In the male the fluctuation of the occurrence of respective grades of maturity was not so simple as in the female, although the complete absence of the wholly spent in grade $I$ was common in both sexes during this period. On the first day of the period the spent male in grade II occupied nearly $29 \%$ of the whole males examined. As shown by the broken line in Fig. $1 \mathrm{~b}$, the frequency curve of the spent male shows two modes as high as $50 \%$, one on the day of new moon and the other two days later. Between these maxima, however, the spent male was completely absent. In contrast to the spent, the mature male attained the first maximum on the second day and the second on the day next the new moon, respectively $50 \%$ and $67 \%$. It is to be noticed that the mature males on the 17 th or two days before the new moon were as much as $50 \%$ but dropped to $20 \%$ next day, nevertheless no spent was found on the 18th. A tentative but very probable explanation of this phenomenon may be that on the 17 th about a half of mature males shed sperms incompletely so that they remained in grade III next day. 

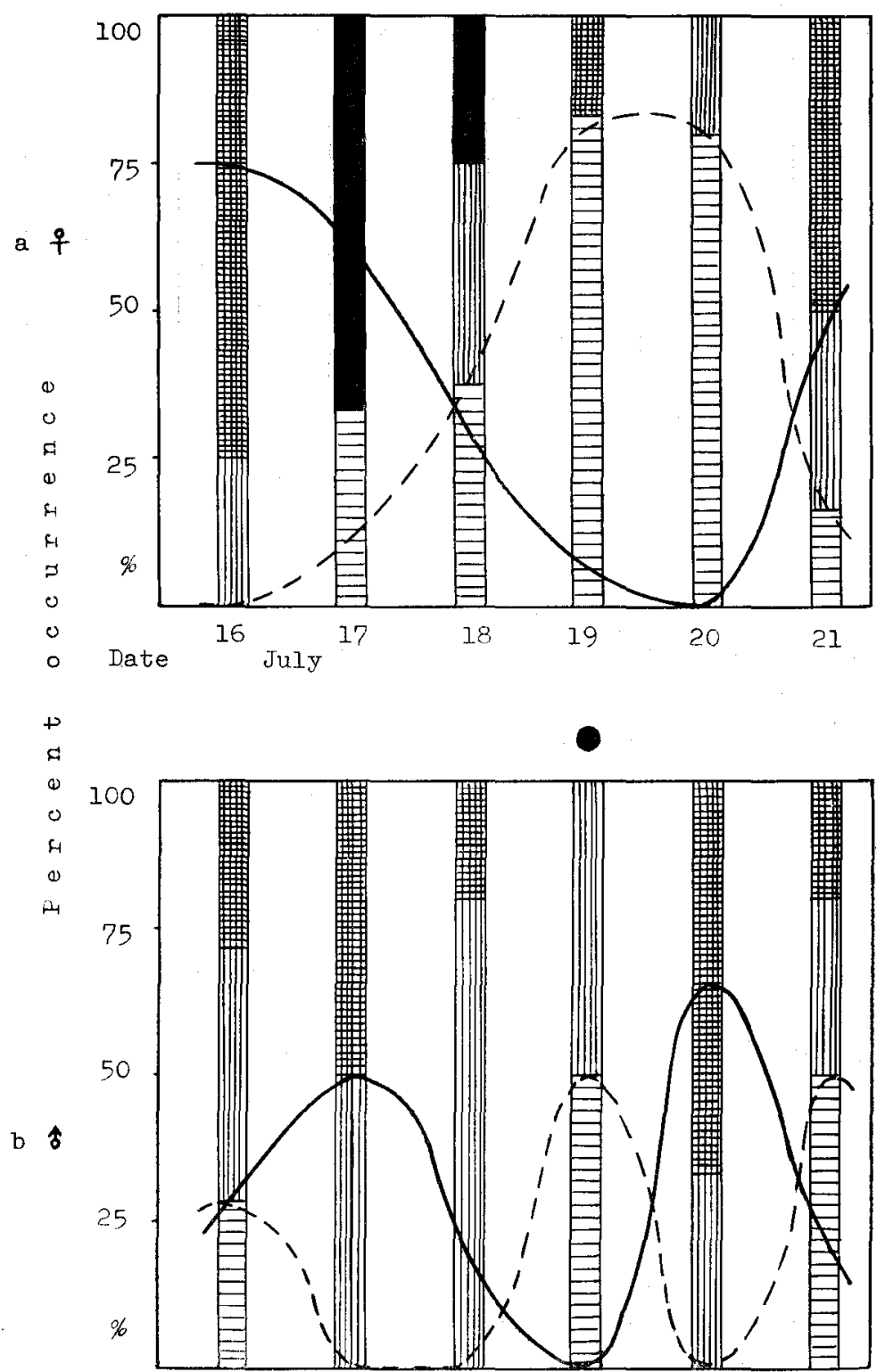

Text-figure 1. Occurrences of individuals of respective maturation grades in percent in the period from July 16 to 21,1966 , with the new moon on the 19th.

-: new moon, $\bigcirc$ : full moon, - : successive changes of mature or fully mature, $\cdots$ : successive changes of spent or wholly spent

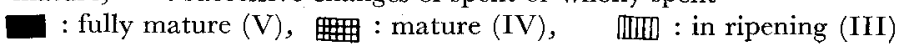

: spent (II), $\square$ : wholly spent (I) 


\section{The second period}

The second period covered six days from July 29 to August 3; the full moon was on August 2. The results of observations are summarized in Table 2b. The striking feature in the sexual maturation in this period was the appearance of wholly spent individuals in both sexes. This was quite consistent with the result of the forced spawning mode on the day of full moon. After the treatment, mature individuals of both sexes became wholly spent and the GT ratio dropped below $5 \%$.

In the female, there was no spent on the first day of the period; spent females appeared on the second day and reached the first maximum on the third day when wholly spent ones occupied $50 \%$ of the examined specimens. Then, on the day of full moon, all the examined specimens were spent and $50 \%$ of them were wholly spent. Next day spent females decreased a little, as females in grade III appeared. As seen in Fig. 2a the occurrence fluctuation of mature females inclusive of grade IV and $\mathrm{V}$ shown by a solid line assumes exactly a mirror image of the fluctuation of spent individuals. On the first day, mature individuals were about $72 \%$ of all examined specimens and $28 \%$ of them were full mature. Full mature individuals disappeared next day, and on the third day no mature individual was detected. A small number of mature individuals appeared on the day before the full moon, but wholly disappeared on the day of full moon and the following day.

In the male fluctuations of both spent and mature individuals in the period were found quite parallel to those in females. However, the spent male never reached $100 \%$ and the mature male never went down to zero throughout the period.

III. The third period

The examination of gonad was made only in three days, August 16, 17 and 18, the new moon being on the 16th. A typhoon passed through the vicinity two days before the new moon and the rough water made the collecting of sea urchins in shore impossible in these two days.

Both females and males were spent or wholly spent on the day of new moon and there was no individual in grade higher than III in both sexes. Similar condition was continued in the following two days in the female, but in the male some individuals in grade III appeared on the next day of new moon. It must be noted that some males marked with an asterisk in Table 2c began the discharge of sperms soon after they were taken out of the water and resultantly they were in the state of spent or nearly spent at the time of examination. It is impossible to guess exactly the grade of maturation in which those males had been when they were collected, although it is clear that they had been in a certain condition ready to shed sperms by slight stimulations. 
Table 2b. Records of examined individuals in the second period of observation.

\begin{tabular}{|c|c|c|c|c|c|c|}
\hline \multirow{2}{*}{ date } & \multicolumn{3}{|c|}{ female } & \multicolumn{3}{|c|}{ male } \\
\hline & $\begin{array}{l}\text { test volume } \\
\text { (cc) }\end{array}$ & GT ratio & $\begin{array}{l}\text { maturity } \\
\text { grade }\end{array}$ & $\begin{array}{l}\text { test volume } \\
\text { (cc) }\end{array}$ & GT ratio & $\begin{array}{l}\text { maturity } \\
\text { grade }\end{array}$ \\
\hline \multirow[t]{7}{*}{ 29/VII } & 50.4 & 20.0 & III & 58.0 & 25.0 & III \\
\hline & 34.0 & 22.1 & III & 54.5 & 30.3 & IV \\
\hline & 35.0 & 30.0 & IV & 35.0 & 34.3 & IV \\
\hline & 42.0 & 46.4 & V & & & \\
\hline & 25.0 & 48.0 & $\mathrm{~V}$ & & & \\
\hline & 32.0 & 35.9 & IV & & & \\
\hline & 26.5 & 34.0 & IV & & & \\
\hline \multirow[t]{8}{*}{$30 / \mathrm{VII}$} & 61.5 & 29.3 & III & 74.5 & 20.8 & III \\
\hline & 39.0 & 34.6 & IV & 35.5 & 33.8 & IV \\
\hline & 31.5 & 39.7 & IV & 39.0 & 15.4 & II \\
\hline & 37.0 & 14.9 & II & 33.0 & 34.8 & IV \\
\hline & & & & 32.0 & 25.0 & III \\
\hline & & & & 25.0 & 20.0 & III \\
\hline & & & & 56.0 & 17.9 & II \\
\hline & & & & 50.0 & 9.0 & I \\
\hline \multirow[t]{7}{*}{$31 / \mathrm{VII}$} & 72.5 & 26.9 & III & 89.0 & 15.7 & II \\
\hline & 72.0 & 10.4 & II & 65.0 & 15.4 & II \\
\hline & 26.5 & 11.3 & II & 32.0 & 20.3 & III \\
\hline & 32.5 & 7.7 & I & 34.5 & 33.3 & IV \\
\hline & 43.0 & 9.3 & I & 29.5 & 16.9 & II \\
\hline & 61.0 & 6.6 & I & 75.0 & 6.0 & I \\
\hline & & & & 37.5 & 8.0 & I \\
\hline \multirow[t]{8}{*}{$1 / \mathrm{VIII}$} & 70.5 & 29.1 & III & 110.0 & 25.9 & III \\
\hline & 113.5 & 18.5 & II & 75.5 & 25.8 & III \\
\hline & 100.0 & 4.5 & I & 65.0 & 17.7 & II \\
\hline & 50.0 & 8.0 & I & 65.5 & 34.4 & IV \\
\hline & 50.0 & 22.0 & III & 49.5 & 7.1 & I \\
\hline & 36.5 & 8.2 & I & 33.0 & 9.1 & I \\
\hline & 27.0 & 13.0 & II & & & \\
\hline & 80.0 & 36.3 & IV & & & \\
\hline \multirow[t]{7}{*}{ 2/VIII } & 79.0 & 10.1 & II & 56.0 & 9.8 & I \\
\hline & 70.0 & 7.9 & I & 88.0 & 19.3 & II \\
\hline & 56.0 & 11.6 & II & 55.0 & 39.1 & IV \\
\hline & 41.0 & 7.3 & I & 63.5 & 14.2 & II \\
\hline & 33.0 & 13.6 & II & 50.1 & 19.8 & II \\
\hline & 50.0 & 5.0 & I & 33.5 & 11.9 & II \\
\hline & & & & 36.0 & 12.5 & II \\
\hline
\end{tabular}


Table 2b. (continued)

\begin{tabular}{c|c|c|c||c|c|c}
\hline \multicolumn{2}{|c|}{ sex } & \multicolumn{3}{|c|}{ female } & \multicolumn{3}{|c}{ male } \\
\cline { 2 - 7 } date & $\begin{array}{c}\text { test volume } \\
\text { (cc) }\end{array}$ & GT ratio & $\begin{array}{c}\text { maturity } \\
\text { grade }\end{array}$ & $\begin{array}{c}\text { test volume } \\
\text { (cc) }\end{array}$ & GT ratio & $\begin{array}{c}\text { maturity } \\
\text { grade }\end{array}$ \\
\hline \multirow{2}{*}{$3 /$ VIII } & 44.5 & 18.0 & II & 41.5 & 15.7 & II \\
& 53.0 & 12.3 & II & 38.5 & 31.2 & IV \\
& 53.0 & 9.4 & I & 30.5 & 14.8 & II \\
& 44.0 & 21.6 & III & 70.5 & 11.3 & II \\
& 45.0 & 17.8 & II & 53.5 & 18.7 & II \\
& 28.5 & 8.5 & I & & & \\
\hline
\end{tabular}

Table 2c. Records of examined individuals in the third period of observation.

\begin{tabular}{|c|c|c|c|c|c|c|}
\hline \multirow[b]{2}{*}{ date } & \multicolumn{3}{|c|}{ female } & \multicolumn{3}{|c|}{ male } \\
\hline & $\begin{array}{l}\text { test volume } \\
\text { (cc) }\end{array}$ & GT ratio & $\begin{array}{l}\text { maturity } \\
\text { grade }\end{array}$ & $\begin{array}{l}\text { test volume } \\
\text { (cc) }\end{array}$ & GT ratio & $\begin{array}{c}\text { maturity } \\
\text { grade }\end{array}$ \\
\hline \multirow[t]{5}{*}{ 16/VIII } & 66.5 & 11.3 & II & 37.5 & 12.0 & II \\
\hline & 35.5 & 14.1 & II & 22.5 & 17.8 & II \\
\hline & 37.5 & 10.7 & II & 19.5 & 18.9 & II \\
\hline & 35.5 & 12.7 & II & 34.5 & 4.4 & I \\
\hline & 37.0 & 14.8 & II & 34.0 & 10.3 & II \\
\hline \multirow[t]{6}{*}{$17 /$ VIII } & 57.5 & 13.4 & II & $* 34.5$ & 21.7 & III \\
\hline & 43.5 & 17.2 & II & $* 35.0$ & 15.7 & II \\
\hline & 46.5 & 17.2 & II & 47.5 & 14.8 & II \\
\hline & 34.5 & 8.7 & $I$ & 33.5 & 23.9 & III \\
\hline & 37.5 & 13.3 & II & 33.0 & 10.0 & II \\
\hline & 34.0 & 19.1 & II & & & \\
\hline \multirow[t]{7}{*}{$18 /$ VIII } & 54.5 & 10.1 & II & $* 76.5$ & 6.5 & I \\
\hline & 41.5 & 10.9 & II & $* 34.5$ & 11.3 & II \\
\hline & 31.5 & 11.1 & II & $* 31.5$ & 6.3 & I \\
\hline & 32.0 & 7.8 & I & 21.5 & 11.6 & II \\
\hline & & & & 20.5 & 7.3 & I \\
\hline & & & & 20.0 & 7.5 & I \\
\hline & & & & 19.5 & 5.1 & I \\
\hline
\end{tabular}

* These individuals began the discharge of sperms just after they were collected. 

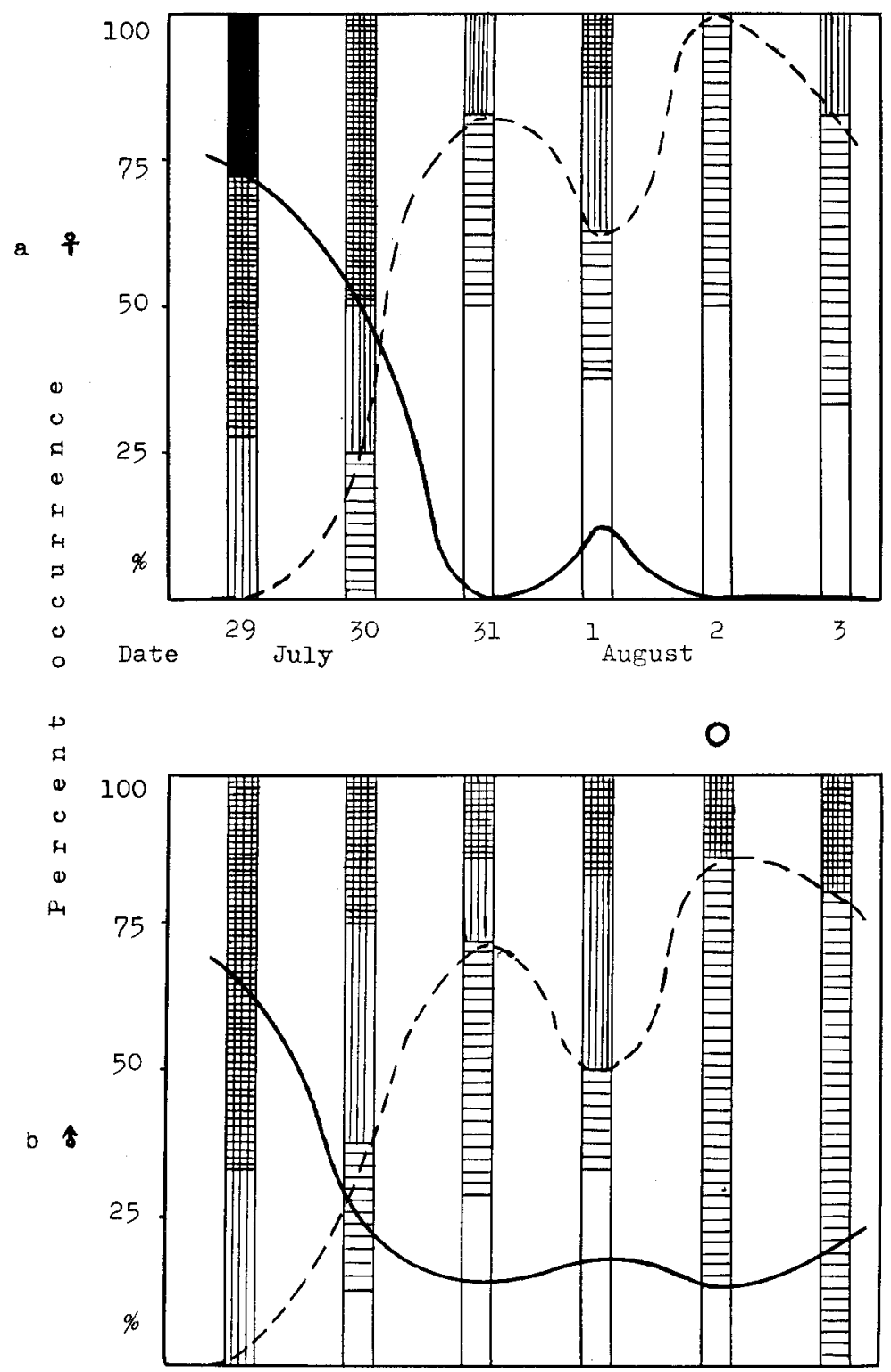

Text-figure 2. Occurrences of individuals of respective maturation grades in percent in the period from July 29 to August 3, 1966, with the full moon on the 2nd. For signs see Text-fig. 1. 


\section{Conclusions}

In many kinds of sea urchins it has been reported that the reproduction is repeated in a certain rhythm correlated with the lunar cycle. In these species mature individuals in both sexes discharge genital products and become spent in a period round the full moon during the breeding season (literatures referred to in reviews by HaRvey (1956) and Boolootian (1966) and in the first paper of this series). However, Moore, Jutare, Bauer and Jones (1963) suggested the possibility of spawning at the time of new moon as well as at the full moon in Lytechinus variegatus, and KoBAyASHI (1967) discussed on such a hemi-lunar periodicity of spawning in Mespilia globulus at Seto. The results obtained in the present observations with Diadema setosum seems to be sufficient to confirm this view. In both sexes, the percent of spent individuals inclusive of wholly spent ones attained the maximum in a few days around the full moon in the beginning of August and fluctuations in the occurrence of mature individuals were found quite in contrast with those of spent ones. These data are enough to admit the enhancement of reproductive activity in the period of full moon as has been reported in some sea urchins. In addition, the occurrence of spent females reached another mode on the day of new moon in July and evidently on both sides of this mode decreased. Changes in the occurrence of mature individuals followed quite reversely those of spent and thus attained a minimum on the next day of the new moon. In a few days ensuing the new moon in August nearly all of examined individuals in both sexes were in the state of spent or nearly spent. These data seemingly point to the possibility of spawning in the period round the new moon. Thus, the reproductive rhythm in Diadema setosum at Seto appears to be of a hemi-lunar periodicity as in Mespilia.

It is noticed that any wholly spent individual was not found in both sexes during the period of new moon in July and the same was true of Mespilia at Seto (Kobayashi 1967). According to Yoshida (loc. cit.) Diadema setosum at Misaki is said to reach maturity in the beginning of July. Such an insufficient evacuation of gonads as indicated by individuals examined in July is considered to be a feature characteristic to the spawning mode in the early period of the breeding season. Fluctuations in the occurrence of individuals in respective maturation grade during the period of the first observation seem to suggest that the gonad will be again full of ripe genital products in a few days after the spawning. This can be explained as follows: the bulk of germ cells do not mature at a time of the spawning, but some part remains immature and become ripe to be discharged within a few ensuing days.

The authors wish to express their thanks to the director and the staff of the Seto Marine Biological Laboratory who gave them every facility for their reserches at the laboratory. 


\section{REFERENCES}

Boolootian, R.A. 1966. Physiology of Echinodermata (Ed. Boolootian, R.A.) Chapter 25. Reproductive Physiology: pp. 590-592. Interscience.

Fox, H.M. 1924a. Lunar periodicity in reproduction. Proc. Roy. Soc. London B. Vol. 95: pp. 523550 .

1924b. The spawning of echinoids. Proc. Camb. Phil. Soc. Biol. Sci. Vol. 1: pp. 7174 (=Biol. Rev.)

HaRvey, E.B. 1956. The American Arbacia and other sea urchins. Chapter 7. Sex and Breeding: pp. 55-57. Princeton.

KЁскĚs, S. 1966. Lunar periodicity in sea urchins. Zeitsch. Naturforsch. 21b: pp. 1100-1101.

Kobayashi, N. 1967. Spawning periodicity of sea urchins at Seto. I. Mespilia globulus. Publ. Seto Mar. Biol. Lab., Vol. 14: pp. 403-414.

Kume, M. and Dan, K. 1957. Embryology of Invertebrate Animals (in Japanese, Ed. Kume, M. and DAN K.). Collection of egg and sperm. Capter 1. General remraks: pp. 7-8. Baifukan, Tokyo.

Moore, H.B., Jutare, T., Bauer, J.G. and Jones, J.A. 1963. The biology of Lytechinus variegatus. Bull. Mar. Sci. Gulf and Carib. Vol. 13: pp. 23-53.

Mortensen, Th. 1938. Contributions to the study of the development and larval forms of Echinoderms. IV. Kgl. Dansk. Vidensk. Selsk. Skr. Naturv. Math. Ser. 9, Vol. 7, No. 3.

Randall, J.E., R.E. Schroeder, and W.A. Starck, 1964. Notes on the biology of the echinoid Diadema antillarum. Carib. J. Sci., 4: pp. 421-433.

Yoshid, M. 1952. Some observations on the maturation of the sea-urchin, Diadema setosum. Ann. Zool. Jap. Vol. 25: pp. 265-271. 